\begin{tabular}{|c|c|c|}
\hline$\underset{P U B L I C A T \text { I O N }}{\operatorname{NF}}$ & $\begin{array}{l}\text { International Journal of Advanced Engineering, Management and Science } \\
\text { (IJAEMS) } \\
\text { ISSN: } 2454-1311 \\
\text { Vol-7, Issue-3; Mar, } 2021 \\
\text { Journal Home Page Available: } \underline{\text { https://ijaems.com/ }} \\
\text { Journal DOI: } \text { https://dx.doi.org/10.22161/ijaems } \\
\text { Article DOI: } \text { https://dx.doi.org/10.22161/ijaems.73.8 }\end{array}$ & 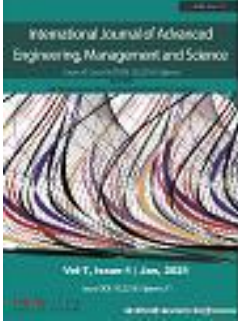 \\
\hline
\end{tabular}

\title{
Sustainable Development Strategies of Restaurants in Cabanatuan City
}

\author{
Alma Pia R. Garcia, Kelvin Julius A. Nueda, Mercedes D. Santos, Rexon R. Fernando \\ Jr., Kelvin E. Rayos, Maureen A. Barangas
}

Graduate School Business Administration Program, Nueva Ecija University of Science and Technology, Cabanatuan City 3100, Philippines

Received: 11 Dec 2020; Received in revised form: 28 Jan 2021; Accepted: 22 Feb 2021; Available online: 19 Mar 2021 (C2021 The Author(s). Published by Infogain Publication. This is an open access article under the CC BY license (https://creativecommons.org/licenses/by/4.0/).

\begin{abstract}
The study delved on determining the sustainable development strategies of restaurants in Cabanatuan City, Philippines. It covered certain areas of sustainable development more particularly in the aspects of Economic, Environmental, and Social. It used the descriptive research design that consisted of 8 randomly selected restaurants using a guided interview and observation to gather data. Findings showed that the restaurants have been adhering to certain areas of sustainable development more particularly in the area of Business Management which ranked first, while some components in the true sense of Corporate Social Responsibility may be lacking. Other noteworthy observations included the loose implementation of waste management, challenges on food supply chain management sustainability is in the offing, and subscription to the use of renewable energy be considered urgent. Overall score on the eight parameters measured in this study pointed to the sustainable development strategies to the verbal interpretation of "often" which has to be elevated to "always" for more sustainable development goals.
\end{abstract}

Keywords - Sustainability, sustainable development, restaurants, hospitality, corporate social responsibility.

\section{INTRODUCTION}

Restaurants are key parts of the hospitality industry, which has the ability to provide and affect the business sector. The Hospitality Industry is a broad category of different fields relating to customer service and satisfaction, as well as the production of goods whether tangible or intangible. These establishments operate on procurement, preparation and distribution or sale of food to their customers. As such, restaurants nowadays are not only focusing on profits but as well as maintaining sustainable development in their operations, thereby achieving sustainability.

According to Brundtland Commission (1987), sustainable development is a development that meets the needs of the present without compromising the ability of future generations to meet their own needs. The same way that
Jones and Allen stated that sustainable development is the pathway to sustainability. Since the latter must be taken further and can only be attained when there is a balance among the three pillars namely environmental, economic and social factors (Purvis et al., 2019). However, sustainability cannot be defined simply as it may seem, likewise with sustainable development. These two elusive words that may require a deeper understanding must be addressed to fully achieve the industry's goal. Sustainable development is a process in which the natural resource base is not allowed to deteriorate (Myers, 1987). The second alternate definition was provided by environmentalist Paul Hawken, who has written about the realization (and the science behind it) that we are using and destroying the earth's resources faster than they can be regenerated and replenished. 
In this study, Economic sustainable development was measured with two standards; Marketing and Business Management. The environmental aspects included four standards; Food and Beverage Management, Water Efficiency, Energy Conservation and Waste Management, while Social standards refer to communication and corporate social responsibility.

Cabanatuan City has now developed into a restaurant hub. New restaurants and food establishments sprung in and out of the city. Cabanatuan, being a progressive and characterized as a first-class city boasts business opportunities including the food and beverage industry. It is credited for its good access to different products and services, with a population of more than 300,000 (2015 census), the city remains to be a good market for food establishments. Present time indicates more than 82 food establishments registered in the city as of 2017 (Business Permit and License Division, Cabanatuan City) notwithstanding the kiosks and proliferation of ambulant food vendors. Since the Philippines is expected to have its population grow bigger than the present year in the next decades, it will entail further reliance on the more efficient and effective use of farmlands to feed the growing population. Such increase requires a second look as regards their practices on sustainable development.

In line with this, this research study aimed to describe the sustainability strategies of restaurants with regard to the triple bottom line approach of sustainability in terms of economic, environmental and social. The findings of the study served as the basis for proposed sustainable regulations and standards.

\section{METHODOLOGY}

The study used the descriptive research design. According to Cristobal and Cristobal (2013), this method of research accurately portrays a population that has been chosen because of some specific characteristics. It is also used to determine the extent or direction of attitudes and behavior. The purpose of this method is to provide a picture of the situation as it naturally happens. It may be used to develop theories, justify practices, aid in making professional judgments, or identify problems with them. The study delimited the respondents to eight restaurants only using purposive sampling based on their asset size which should be more than Php1 million in capitalization, not less than 10 years in operation, and whose number of employees are 15 and above. It further employed unstructured interviews and observation for validation purposes in data gathering. Likert scale was utilized in determining the degree to which the strategies were applied by the respondents of restaurants. The interpretation of the Likert scale is based on the degree of frequency where the option is Always, Often, Seldom, and Never, hence the scale in the responses is shown in Table 1.

Table 1. Point, Range and Verbal Analogy

\begin{tabular}{|c|c|c|}
\hline Point & Range & Verbal Analogy \\
\hline 4 & $3.26-4.0$ & Always (applied every time) \\
\hline 3 & $2.51-3.3 .25$ & $\begin{array}{c}\text { Often (applied most of the } \\
\text { time) }\end{array}$ \\
\hline 2 & $1.76-2.50$ & Seldom (applied rarely) \\
\hline 1 & $1.00-1.75$ & Never (not ever applied) \\
\hline
\end{tabular}

\section{RESULTS AND DISCUSSION}

1. Describe the sustainable development strategies of the restaurants

Tables 2 to 9 show the summary of the degree of practice or application of the sustainable development strategies of restaurants.

Table 2. Sustainable Development Strategies - Economic (Marketing)

\begin{tabular}{|c|l|c|c|}
\hline No. & \multicolumn{1}{|c|}{ Item Statement } & Weighted Mean & Verbal Interpretation \\
\hline 1 & $\begin{array}{l}\text { Makes use of social media sharing incentives } \\
\text { (Facebook, Instagram, Twitter) }\end{array}$ & 3.75 & Always \\
\hline 2 & Uses print as a marketing medium & 3.12 & Often \\
\hline 3 & Adopts a loyalty program & 3.12 & Often \\
\hline 4 & Rates are competitive with other restaurants & 3.25 & Seldom \\
\hline 5 & Uses digital media in taking orders & 3.25 & Often \\
\hline & Overall Weighted Mean & 3.10 & \\
\hline
\end{tabular}


Among all the items indicated in Table 2, the restaurants make use of social media sharing incentives such as Facebook, Instagram and Twitter constantly with a mean score of 3.75 and an interpretation of Always. On the other hand, it is safe to say that most of the establishments rarely use digital media in taking orders with a mean of 2.25 . Note that this survey was conducted before the onset of the covid-19 pandemic the reason, too, that online platforms had a low score.
The use of any form of media makes efficient the business operation attuned with the times and widens the horizon particularly its customer base. It also boosts competition among the players to improve the product or services and breeds innovation of methods and processes. This in return would be beneficial to consumers and stakeholders and adds economic value to owners toward long-term business sustainability. This also promotes operative value-chain management.

Table 3. Sustainable Development Strategies - Economic (Business Management)

\begin{tabular}{|c|l|c|c|}
\hline No. & \multicolumn{1}{|c|}{ Item Statement } & \multicolumn{1}{|c|}{$\begin{array}{c}\text { Weighted } \\
\text { Mean }\end{array}$} & Verbal Interpretation \\
\hline 1 & Hires employees within the area of operation & 3.75 & Always \\
\hline 2 & Pays employees on time & 3.75 & Always \\
\hline 3 & Uses a Point-of-Sale system & 3.37 & Often \\
\hline 4 & Accounts day to day finances of the business & 3.62 & Always \\
\hline 5 & Allots sufficient budget for sustainability measures & 3.50 & Often \\
\hline 6 & Employees are regularly given training on customer & 3.37 & Always \\
\hline
\end{tabular}

The data suggest that item numbers 1 and 2 have the highest mean of 3.75 and a verbal interpretation of Always. Overall weighted mean indicates 3.56 and interpreted as Always. This would mean that the Economic Sustainable Development Strategies in terms of Business Management specifies a degree of applicability and should therefore be considered as manageable and feasible. The data further implies that restaurant owners, who are leaders and managers (Zabala, et al., 2018), are subservient to a law which is an indication of good business practice, and are apparently working within the framework of the understanding of business ethics. Ethical behavior creates stability and positive effects and a respectable reputation for the company, good image in the community and the stakeholders as well. It also fosters a stronger bond among the employees in the company, hence making it a necessary component for the survival of the business and its sustainability.

Table 4. Sustainable Development Strategies - Environmental (Food and Beverage Management)

\begin{tabular}{|l|l|c|c|}
\hline No. & Item Statement & Weighted Mean & Verbal Interpretation \\
\hline 1 & $\begin{array}{l}\text { Food ingredients used in the restaurant are sourced } \\
\text { locally or within the region }\end{array}$ & 3.12 & Often \\
\hline 2 & Beverages offered in the restaurant are sourced locally & 3.25 & Often \\
\hline 3 & Has an accredited supplier of food and beverages & 3.87 & Always \\
\hline 4 & Produces its own ingredients & 2.25 & Seldom \\
\hline 5 & Changes or modifies the menu regularly & 2.37 & Often \\
\hline & Overall Weighted Mean & 2.97 & \\
\hline
\end{tabular}

Table 4 reveals that in terms of Food and Beverage Management, the restaurants "always" have an accredited supplier with a mean score of 3.87 , while on the area of producing its own ingredients have a mean score of 2.25 and verbally interpreted as "seldom". 
What the restaurants in Cabanatuan City lack are the production of their own materials and ingredients. "Growing your own ingredients has the potential to produce food in a sustainable way." This is according to an executive chef, Ben Kramer. As an own producer, it eliminates the uncertainty of availability or break in supply (Manitoba, 2013). The issue of supply-chain management also crops up as a concern here especially in the areas of the value chain and eventually the efficient and equitable use of resources.

Sustainable consumption and production in the UN's 2030 Agenda calls for changes in the patterns in the production and consumption of goods of countries to mitigate the effects of economic progress on the environment (Development Asia, 2020)

Table 5. Sustainable Development Strategies - Environmental (Water Efficiency)

\begin{tabular}{|l|l|c|c|}
\hline No. & Item Statement & $\begin{array}{c}\text { Weighted } \\
\text { Mean }\end{array}$ & Verbal Interpretation \\
\hline 1 & There is a regular potability water test in the restaurant & 3.12 & Often \\
\hline 2 & $\begin{array}{l}\text { Has a self-service policy for drinking water or only upon } \\
\text { request by customers }\end{array}$ & 2.50 & Seldom \\
\hline 3 & Serves water upon guests have been seated & 3.12 & Seldom \\
\hline 4 & The restroom uses waterless urinals or water-efficient toilets. & 2.12 & Always \\
\hline 5 & Water conservation guidelines are implemented & 3.75 & Often \\
\hline & Overall Weighted Mean & 2.92 & \\
\hline
\end{tabular}

The survey reveals that restrooms or toilets in these establishments are not water-efficient and do not have waterless urinals with a mean score of 2.12 and interpreted as seldom.

The findings confirm with a 2016 Manila Times report which stated the need for water conservation in the Philippines not only in the restaurant industry but as a whole. The country is likely to face shortages of water for drinking, sanitation, agriculture, and industry within the next ten years unless stronger management and conservation efforts are initiated.

Table 6. Sustainable Development Strategies - Environmental (Energy Conservation)

\begin{tabular}{|l|l|c|c|}
\hline No. & Item Statement & $\begin{array}{c}\text { Weighted } \\
\text { Mean }\end{array}$ & $\begin{array}{c}\text { Verbal } \\
\text { Interpretation }\end{array}$ \\
\hline 1 & Makes use of solar panels or other forms of alternative energy & 1.37 & Never \\
\hline 2 & A light-emitting diode (LED) is used in all lighting system & 3.12 & Often \\
\hline 3 & Uses inverter technology air conditioning units & 2.87 & Often \\
\hline 4 & Uses inverter technology refrigerators & 1.73 & Seldom \\
\hline 5 & Open dining area (al fresco) & 3.75 & Seldom \\
\hline 6 & Energy-saving guidelines are strictly implemented & 2.54 & Often \\
\hline & Overall Weighted Mean & 2.37 \\
\hline
\end{tabular}

A mean of 1.37 or "never" was reflected in the use of solar panels as an alternative form or source of energy. The use of solar panels in the Philippines is in its initial stage. Moreover, the cost of installation can be prohibitive, too. As regard, the provision of an open dining area can be far from incorporating in building design because the Philippines has a hot climate, and people are seeking air-conditioned areas for their convenience. 
Table 7. Sustainable Development Strategies - Environmental (Waste Management)

\begin{tabular}{|l|l|c|c|}
\hline No. & Item Statement & $\begin{array}{c}\text { Weighted } \\
\text { Mean }\end{array}$ & $\begin{array}{c}\text { Verbal } \\
\text { Interpretation }\end{array}$ \\
\hline 1 & Engages in garbage segregation & 3.12 & Often \\
\hline 2 & $\begin{array}{l}\text { The use of plastic materials is discouraged instead, it uses recyclable or } \\
\text { biodegradable food containers }\end{array}$ & 2.85 & Often \\
\hline 3 & Uses recyclable takeaway bags & 3.00 & Often \\
\hline 4 & Conducts inventory in order to compare purchase and quantity of garbage & 2.76 & Often \\
\hline 5 & The restaurant is engaged in the 3Rs: Reduce, Reuse and Recycle & 3.00 & Often \\
\hline 6 & Waste management guidelines are strictly implemented & 2.55 & Often \\
\hline & Overall Weighted Mean & 2.88 & Often \\
\hline
\end{tabular}

Of the item statements listed above, number 6 or waste management guidelines are strictly implemented in the restaurants studied. A mean score of 2.88 or "often" had been discovered. This confirms the law pertaining to the Solid Waste Management Act of 2000 or Republic Act (RA) 9003. The law declares the policy of the state in adopting systematic, comprehensive and ecological solid waste management program that ensures the protection of public health and the environment. Apparently, the restaurants are yet to apply recyclable takeaway bags as their primary food packaging and to engage in the 3Rs-
Reduce, Re-use and Recycle. Both items have mean scores of 3.0 respectively and interpreted as "often".

However, based on the observation of the researchers, a few of them ( 3 or $38 \%$ ) are remiss in waste segregation. These are the restaurants located outside the malls. More so, there are countless health hazards and damage to humans and the environment because of improper waste segregation and disposal. Although in the Philippines, there is enough law to address this problem, Local Government Units (LGUs) and other concerned agencies struggle to implement such.

Table 8. Sustainable Development Strategies - Social (Communication)

\begin{tabular}{|l|l|c|c|}
\hline No. & \multicolumn{1}{|c|}{ Item Statement } & $\begin{array}{c}\text { Weighted } \\
\text { Mean }\end{array}$ & $\begin{array}{c}\text { Verbal } \\
\text { Interpretation }\end{array}$ \\
\hline 1 & $\begin{array}{l}\text { Reminders to limit the use of water, conserve energy and minimize waste } \\
\text { are posted conspicuously inside the restaurant for employees to see }\end{array}$ & 3.5 & Always \\
\hline 2 & $\begin{array}{l}\text { Reminders to limit the use of water, conserve energy and minimize waste } \\
\text { are posted conspicuously inside the restaurant for customers to see }\end{array}$ & 1.71 & Seldom \\
\hline 3 & Sustainability measures are posted on the restaurant's social media page & 2.11 & Seldom \\
\hline 4 & No Leftover policy is adopted in the restaurant & 1.75 & Seldom \\
\hline 5 & Food and beverage items are individually described on the menu & 2.31 & Seldom \\
\hline & Overall Weighted Mean & 2.28 & Seldom \\
\hline
\end{tabular}

Of all the items stated, number 1 got the highest mean score of 3.50 and verbally interpreted as "always". This indicates that communication plays a vital role in promoting sustainability. The reminders to limit the use of water and energy as well as minimize waste are placed conspicuously for everyone to see, this is a good gauge of sustainability in communication among restaurants. Seemingly, a mean of 1.75 or "seldom" was gained by the No-left over the policy of restaurants. Food wastage is a major concern among industry practitioners and should be dealt with immediately. 
Table 9. Sustainable Development Strategies - Social (Corporate Social Responsibility)

\begin{tabular}{|l|l|c|c|}
\hline No. & Item Statement & $\begin{array}{c}\text { Weighted } \\
\text { Mean }\end{array}$ & $\begin{array}{c}\text { Verbal } \\
\text { Interpretation }\end{array}$ \\
\hline 1 & $\begin{array}{l}\text { Conducts social and community development activities like tree planting and } \\
\text { gift-giving }\end{array}$ & 2.00 & Seldom \\
\hline 2 & $\begin{array}{l}\text { Actively supports/join Government and Non-Governmental Organizations' CSR } \\
\text { programs and projects }\end{array}$ & 1.75 & Seldom \\
\hline 3 & Supports charitable organization & 2.00 & Seldom \\
\hline 4 & Supports local food suppliers by buying their goods & 2.75 & Often \\
\hline 5 & Provides health benefits to employees & 3.37 & Often \\
\hline 6 & Gives financial support for students' education & 1.75 & Seldom \\
\hline & Overall Weighted Mean & 2.27 & Seldom \\
\hline
\end{tabular}

It is discouraging to note that the restaurants have not acquired a definitive social responsiveness program as other companies do. The findings also reveal that they are not actively supporting government and non-governmental organizations' CSR programs as well as giving financial support to student's education is not among the priorities of these establishments. Both items indicated a mean of 1.75 , and interpreted as "seldom"

The findings run parallel to the study of Montalbo (2015) which resulted that Corporate Social Responsibility (CSR) related mission/vision is clearly not embedded in the institutional websites of fast food restaurants. On a good note, the personal/social proximity approach is highly evident in the health benefits provided to employees with a mean of 3.37 and interpreted as "often". The combined mean weight of 2.27 is interpreted as "seldom" which could mean that restaurants need to improve CSR strategies in their respective establishments.

Tong and Wong (2016) stressed that CSR can improve an organization's competitive edge and sustainability. In addition, CSR together with the concept of 3Rs (Reduce, Reuse and Recycle) can enhance the corporate image and its effect on the performance of fastfood restaurants.

\section{CONCLUSION AND RECOMMENDATIONS}

\section{Conclusion}

Based on the findings of the study, the following conclusions were drawn and ranked accordingly based on their weighted mean:
Rank 1. As to Economic- Business Management. This aspect of sustainable development strategies got a verbal interpretation of "often" that indicates that restaurants regularly employ appropriate tools in their business activities.

Rank 2. As to Economic - Marketing. This aspect of sustainable development strategies got a verbal interpretation of "often" as many of them constantly practice innovative selling techniques attuned with the times.

Rank 3. As to Environmental - Food and Beverage Management. This aspect of sustainable development strategy got a verbal interpretation of "often". However, they seldom produce their own ingredients and rarely change their menus which may imply unsustainable in the long run.

Rank 4. As to Environmental - Water Efficiency. This aspect of sustainable development strategy got a verbal interpretation of "often". On the contrary, some areas need still to be achieved as not all of them use waterless urinals, and some policies in water conservation not fully implemented.

Rank 5. As to Environmental - Energy Conservation. This aspect of sustainable development strategy got a verbal interpretation of "often". Noticeable in the findings is that establishments are not yet inclined to use them more friendly (renewable) solar energy.

Rank 6. As to Environmental - Waste Management. This aspect of sustainable development strategy got a verbal interpretation of "often". The "often" WM suggests that this area may still lack comprehensive and all-encompassing policy as regard waste management. 
Rank 7. As to Social - Communication. This aspect of sustainable development strategy got a verbal interpretation of "seldom". This further indicates that rarely do restaurants are aware to convey to employees and stakeholders the importance of communicating effectively environmental concerns.

Rank 8. As to Social - Corporate Social Responsibility. This aspect of sustainable development strategy got a verbal interpretation of "seldom". Under this aspect that restaurants still lack the spirit and meaning of true corporate social responsibility.

\section{Recommendations}

In the light of the conclusions derived therefrom, the following recommendations are hereby made:

1. The restaurants should adopt measures to be more environmentally conclusive; producing their own ingredients can promote farm-to-table as well as modifying the menu to adhere to seasonal crop changes.

2. Corporate Social Responsibility must be promoted and emphasized (Mina, et al., 2019 as cited by Balaria, et al, 2021) among the restaurants particularly in conducting social and community development activities, supporting government and non-governmental organizations' CSR programs, and giving financial assistance to students' education as practiced by some companies.

3. Regulations and standards must be set to provide guidance to restaurateurs and future owners to be sustainable in their operations.

4. An organized union of restaurant owners must be established to pioneer sustainability measures in their operations, as well as, promote camaraderie and bring about community togetherness in this area.

5. Lastly, further researches on sustainable development and sustainability could be expanded to include other measures which could provide greater insights to the restaurant industry. It can also be extended to hotels and accommodations and other forms of businesses.

\section{Proposed Sustainable Regulations and Standards}

The researcher proposed Regulations and Standards-based on the UNDP Sustainable Development Goals - Three Pillar Impacts. The following can be adopted.

1. Impact Management - provide tools to support investor and business contributions to the SDGs.

2. Impact Intelligence - data that provide insights where development is needed in cognitive intelligence and thinking skills (Subia, et al., 2020) of restaurant owners.

3. Impact Facilitation - connect businesses to provide insights and tools that translate opportunities to action.

\section{REFERENCES}

[1] Aragon-Correa, J. et al. (2015) Sustainability issues and hospitality and tourism firms' strategies: Analytical review and future directions. International Journal of Contemporary Hospitality Management 27(3):498-522. Retrieved from https://www.researchgate.net/publication/277636992_Susta inability_issues_and_hospitality_and_tourism_firms'_strate gies_Analytical_review_and_future_directions

[2] Balaria, F. E., Fronda, J. G., Baligod, E. G., Santiago, S. R., Sula, C. T., \& V. Pelayo, E. V. (2021). Junkshop Industry as Waste Recycling Business: A Green Response towards Economic Sustainability and Social Responsibility. International Journal of Environment, Agriculture and Biotechnology, 6(1). Retrieved from http://journalrepository.com/index.php/ijeab/article/view/3014.

[3] Baldwin, C. et al. (2011) Restaurant and foodservice life cycle assessment and development of a sustainability standard. The International Journal of Life Cycle Assessment. Springer Link. 16-49 (2011). Retrieved from https://link.springer.com/article/10.1007/s11367-010-0234$\underline{x}$

[4] Burton, L. (2020) How to Improve Sustainability in Restaurants, High-Speed Training. Retrieved from https://www.highspeedtraining.co.uk/hub/improvesustainability-in-restaurants/

[5] Campbell, L. (2013) Green House Effect. Posted July 1, 2013. Retrieved from https://www.fcsi.org/foodserviceconsultant/worldwide/green-house-effect/

[6] Camus, M. (2018). PH is a world leader in social media usage. Philippine Daily Inquirer, Manila. February 15, 2018. Retrieved from http://business.inquirer.net/246015/ph-world-leader-socialmedia-usage

[7] Chan, N. et al. (2011) Investigation of Social Media Marketing: How Does the Hotel Industry in Hong Kong Perform in Marketing on Social Media Websites? S.1. : Journal of Travel \& Tourism Marketing, Vol. 28

[8] Claridades, J. (2014). Hotel Restaurant Institutional Food Service Sector GAIN Report. USDA Foreign Agricultural Service. Retrieved from: https://gain.fas.usda.gov/Recent\%20GAIN\%20Publications Food\%20Service\%20\%20Hotel\%20Restaurant\%20Institutional_Manila_Philippi nes_12-29-2014.pdf

[9] Davies, T. \& Konisky, D. (2000) Environmental Implications of the Foodservice and Food Retail Industries. https://media.rff.org/documents/RFF-DP-00-11.pdf 
[10] Edralin, D. \& Castillo, P. (2001). An In-Depth Study on the Hotel and Restaurant Industry in the Philippines. De La Salle University, Manila. Retrieved from https://www.researchgate.net/publication/265150045_An_I ndepth_Study_on_the_Hotel_and_Restaurant_Industry_In_ the_Philippines_Submitted_by

[11] Ellliot, J.A. (2009) Sustainable Development, International Encyclopedia of Human Geography, 2009, pp. 117-131. Retrieved from https://www.sciencedirect.com/science/article/pii/B978008 $\underline{0449104001243}$

[12] Freeman, E. (2011). Restaurant Industry Sustainability: Barriers and Solutions to Sustainable Practice Indicators, Arizona State University, USA. Retrieved from https://repository.asu.edu/attachments/56588/content/Freem an_asu_0010N_10634.pdf

[13] Hollis, M. (2020) 7 Restaurant Sustainability Practices for 2020, Upserve by Lightspeed. Retrieved from https://upserve.com/restaurant-insider/restaurantsustainability-trends/

[14] Jacobs, G. \& Klosse, P. (2016) Sustainable restaurants: A research agenda. Research Centre Gastronomy in Food Service, Zuyd University of Applied Sciences, Maastricht, The Netherlands

[15] Ju, S. \& Chang H. (2016) Consumer perceptions on sustainable practices implemented in foodservice organizations in Korea. Nutr Res Pract. 2016 Feb; 10 (1): 108-114. doi: $10.4162 / \mathrm{nrp} .2016 .10 .1 .108$ https://www.ncbi.nlm.nih.gov/pmc/articles/PMC4742303/

[16] Mensah, J. (2019) Sustainable development: Meaning, history, principles, pillars, and implications for human action: Literature review, Published Sept. 8, 2019, Taylor \& Francis online. Retrieved fromhttps://doi.org/10.1080/23311886.2019.1653531

[17] Mancheva-Ali, O. (2018) Opportunities to Achieve a Sustainable Restaurant Business, SSRN Electronic Journal, DOI: $10.2139 / \mathrm{ssrn} .3283694 . \quad$ Retrieved from https://www.researchgate.net/publication/329135008_Oppo rtunities_to_Achieve_a_Sustainable_Restaurant_Business

[18] Maynard, D. et al. (2020) Environmental, Social and Economic Sustainability Indicators Applied to Food Services: A Systematic Review.

[19] Mina, J.C., Barlis, P.T., Vega, N.C. and Subia, G.S. (2019) Corporate Social Responsibilities of Selected Resorts in Cabanatuan City, Nueva Ecija, Philippines. Open Access Library Journal,

6: e5292.https://doi.org/10.4236/oalib.1105292

[20] Muralikrishna, I. \& Manickan, V. (2017) Sustainable Development, Environmental Management. Retrieved from https://www.sciencedirect.com/book/9780128119891/envir onmental-management

[21] Murphy, K. (2012) The social pillar of sustainable development: A literature review and framework for policy analysis, Sustainability: Science, Practice, and Polic. 8 (1):15-29. Retrieved from https://www.researchgate.net/publication/286461953_The_ social_pillar_of_sustainable_development_A_literature_rev iew_and_framework_for_policy_analysis
[22] Prigge, J. (2017) Time to Fire Up Restaurant Sustainability - Here's How, Retrieved from https://www.environmentalleader.com/2017/12/time-firerestaurant-sustainability-heres/

[23] Purvis, B. et al. (2019) Three pillars of sustainability: in search of conceptual origins, Springer, Sustainability Science, DOI: 10.1007/s11625-018-0627-5. Retrieved from https://www.researchgate.net/publication/327404334_Thre e_pillars_of_sustainability_in_search_of_conceptual_origin $\underline{s}$

[24] Subia, G., Marcos, M., Valdez, A., Pascual, L. \& Liangco, M.(2020). Cognitive Levels as Measure of Higher-Order Thinking Skills in Senior High School Mathematics of Science, Technology, Engineering, and Mathematics (STEM) Graduates. Technology Reports of Kansai University. Volume 62, Issue 3, pp 261-268.

[25] Zabala Jr., B., Gutierrez, M. and Subia, G. (2018) Needs Assessment of Barangay Tanawan, Dingalan, Aurora towards a Proposed Oplan Development Program. International Journal of Environment, Agriculture, and Biotechnology, 3 , 2163-2167. https://doi.org/10.22161/ijeab/3.6.28 [Citation Time(s):1] 